\title{
An Analysis of Bank Competiveness, Financial Intermediation and Entrepreneurship Development in African Economies
}

\author{
PATRICK O. EKE ${ }^{1}$, ACHUGAMONU BEDE U. ${ }^{2 *}$, SIKIRU O. ASHAMU $^{3}$, \\ ABIOLA A. BABAJIDE ${ }^{4}$ \\ Department of Banking \& Finance ${ }^{1-4}$, \\ Lagos State University, Ojo, Lagos State ${ }^{1,3}$ \\ Covenant University, Ota, Ogun State ${ }^{2,4}$ \\ NIGERIA
}

\begin{abstract}
Given probable nexus between financial intermediation and entrepreneurship development, this paper uses multivariate regression techniques to test the impact of bank competitiveness on the nexus in fortytwo African economies. With data obtained from the World Development Indicators, the results reveal that lending rates, the proxy for financial intermediation positively impacts business start-up-cost, the proxy for entrepreneurship, while bank competitiveness negatively impacts business start-up-cost, which suggests that banking competitiveness has the capacity to improve entrepreneurship in African economies. The region's economies should reduce monetary base rates to single digit; advanced liberalization of the financial industry; encourage stronger competition through digital finance; lessen the requirements for new conventional bank entry; provide fiscal support for increased bank branching.
\end{abstract}

Keywords: Entrepreneurship, Financial intermediation, Bank competitiveness, financial liberalization.

Received: Juuary 10, 2021. Revised: August 6, 2021. Accepted: August 17, 2021. Published: August 31, 2021.

\section{Introduction}

In Africa, entrepreneurship development may have been experiencing critical challenges from poor institutional support, skill gap, and access to finance, among others. However, there seem to be increasing finance gap by the prevalence and perplexity (in nature and structure) of financial capital which may not be sustainable for pressing entrepreneurial needs in the region, as need for engagement of idle labour resource exacerbates. The measure of the contribution of liberalization and deregulation policies in the region is in contest. Perhaps, due to unfriendly investment policies, Africa's financial intermediation (hereafter FI) industry is still largely dominated by short-term finance, that is, commercial banks and microfinance banks, that may be unhelpful for genuine long-term risk taking venture. This paper contributes to bank competitiveness literature, as deeper knowledge of the role of bank competitiveness may inform new government policies needed to attract finance for more entrepreneurial inclusion in the region.

Though, since the 1990s, many sub-Sahara African (SSA) governments embraced financial liberalization and deregulation policies, albeit insincerely, and given wave of increasing global technological innovation, and growth of financial markets, the financial sector in SSA has been underperforming in the advancement of credit to start-ups and genuine entrepreneurs [1]. That is, the financial system have been short of competitiveness, characterized by high bank interest margin, and weak impact on the real sector, perhaps, due to less ingraining of financial market institutions, relative to growth of banking markets. The OECD defined competiveness as a nation's ability to produce goods and services that meet the test of international market while simultaneously maintaining and expanding the real income of its citizen [2]. Narrowing it down to the banking industry, the main financial engineering for growth in developing economies [3], implies the ability of deposit money banks to provide long-term funding that could spur growth and increased real per capita income through sustained entrepreneurship. According to the World Bank, there is a link between FI and entrepreneurship which is critical for rapid economic diversification, widespread prosperity and development $[4,5,6]$. Changes in the capacity, process, and perception of the African people to entrepreneurship may be influenced by extent of access to finance, [5,7]. For example, the Asia's 'growth miracle' of the 1990 was noted for 
increased entrepreneurial opportunities devoid of widening income disparity [4]. In Africa however, the business of bank intermediation is often limited by excessive credit risk, among others, as price of loan may not bear all the potential riskiness, The financial structure type and its architectural depth matter for effective and efficient FI outcome [9], while the state of bank competitiveness may further advance the degree and quality of FI $[10$, 11]. African economies, unarguably, are dominated by commercial banking, that is essentially commercial enterprises' focused, with little capacity for risk taking in industrial and manufacturing entrepreneurship, particularly the small and medium scale manufacturing start-ups. For instance, despite indication of relative increasing liquidity in most financial system in the region, lending rate and the associated cash reserve ratio (CRR) have remained high at second digit in Nigeria [12], an economy noted to operate high interest rate margin among global peers [13], such that genuine entrepreneurial access to finance remain a tough nut.[14] study on agent banking and financial inclusion found that there is need to make more bank products and services available to the rural communities to engender financial inclusive growth. particularly for start-ups, given the limited saving capacity. An equilibrium savings rate may be required to prompt improved capital formation for real investment growth and help to stabilize the financial system [8].

Entrepreneurial development in Africa more or less lacks fiscal and financial support, as the region records the highest failure of entrepreneurial ventures in start-ups, in their first five years among global peers [1]. On this note, there is through phase from right finance mode, at the right cost and tenure for prospective risk taking capacity (entrepreneurship). Moreover, in terms of bank proximity, facts from bank per capita, a measure of competitiveness, have not been encouraging relative to global peers. Such that, combined with cost-to-start business dilemma, both have made access to finance for prospective entrepreneur very weak incentive as evidenced in the facts on regional statistics in Table $\mathbf{1}$ from 2005 to 2019. Sub-Sahara African economies lag behind global average and other regions' economic performance in the bank-per-capita and cost-to-start business statistics, measured by percentage of gross national income (GNI) per capita, as revealed in Table 1.

Table 1: Trend of bank- per-capita and cost-to-start business procedure (\% of GNI per capita)

\begin{tabular}{|l|c|l|l|l|l|l|l|l|}
\hline Regions \& World & \multicolumn{3}{|c|}{ Bank branch per capita } & \multicolumn{3}{l|}{ Cost to start business (\% of IPC) } \\
\hline & 2005 & 2010 & 2017 & 2019 & 2005 & 2010 & 2017 & 2019 \\
\hline East Asia \& Pacific & 12.62 & 10.04 & 9.61 & 10.1 & 44.94 & 25.73 & 16.65 & 15.8 \\
\hline South Asia & 7.4 & 8.03 & 10.20 & 10.4 & 45.20 & 24.54 & 21.36 & 8.3 \\
\hline ECA & 12.60 & 22.3 & 24.10 & 24.94 & 13.33 & 7.47 & 3.63 & 3.3 \\
\hline North America & 33.28 & 29.73 & 25.98 & 25.0 & 0.9 & 0.4 & 0.75 & 0.70 \\
\hline LAC & 11.80 & 13.60 & 13.8 & 13.6 & 58.68 & 8.21 & 36.47 & 30.6 \\
\hline MENA & 11.36 & 13.7 & 13.7 & 11.2 & 67.4 & 38.1 & 19.8 & 16 \\
\hline sub-Sahara Africa & 1.53 & 3.36 & 4.44 & 4.4 & 205.7 & 104.79 & 49.91 & 37.6 \\
\hline World & 9.50 & 10.81 & 11.9 & 11.51 & 84.35 & 44.68 & 25.32 & 19.80 \\
\hline
\end{tabular}

Source: The World Bank-IBRD, IDA Data (doingbusiness.org). World Development Indicator (WDI, 2017) Private sector database, www.data.worldbank.org/indicator. IPC is Gross National Income per capita; ECA is Europe \& Central Asia; LAC is Latin America \& Caribbean; MENA is Middle East \& North Africa

Relative to prior studies, the objective is to examine the role of bank competitiveness in the relationship between FI and entrepreneurship in African economies, by the use of multivariate panel techniques. The research questions argued are, firstly, to what extent does FI impacts entrepreneurship development in African region? Secondly, to what extent is bank competitiveness helpful for entrepreneurship development?
Hypotheses tested thereof are that the FI does not significantly impact entrepreneurship development, and secondly, that bank competitiveness does not matter for entrepreneurship development. The study's result reveals that high lending rate (the proxy for FI) negatively impacts entrepreneurship (proxied by cost-to-start business), and that, bank competitive could reduce cost-of-start business in the region. The results may be applicable to 
economies in developing world having fairly similar culture, institutions and economic structure. The implication of the result is that bank competitiveness is required for entrepreneurial growth. Government should encourage wide range of financial competitiveness by issuing more banking licensing at low entry cost, and improved bank branching, particularly rural branching, more non-bank FIs and foreign bank institutions, to make entrepreneurial finance available and at cheaper rate for start-ups.

\section{Literature Review}

\subsection{Theoretical Review}

The link from FI to economic growth and development may not have been well researched, particularly in developing economies. Indeed, the debate about the interactions and to what extent the financial system is functionally linked to economic development process is replete and still receiving intellectual thoughts [15]. Nevertheless, the FI industry in African would be more effective if constantly focused and undated, given its position as one of the poorest region, and the role of the banking firm as catalyst for capital formation and productivity [16]. Moreover, the mechanics of FI is a factor in the divergent and convergence growth theories. According to [17], FI plays dominant role in economic development, and may have to be more innovated in African region [17]. A recent contemporary study that re-examined role of FI on economic growth can be found in [18].

\subsection{Empirical Literature}

Considerable number of studies on how the structure of an economy's financial system could spur entrepreneurship and growth adorn financial literature. In a study conducted by [9], the result of larger number of countries sampled, supports the idea that development finance stimulate entrepreneurial innovations.[19 ] affirms that technological innovation can be spurred by access to finance whereby entrepreneurs are identified and credit extended to them to initiate new processes or to produce entirely new goods. [20] assesses the vertical structure of a country's finance system, and opine that access to credit alone may not solve the financial requirements of an entrepreneur as evidenced with the global financial crisis of 2007 which shows that external shocks can have far reaching implication on the flow of finance to regions in Africa. The study asserts that, mobilizing funds within the economy is key to sustainable economic growth and investment.
In this regard, the onus is on banks as the prime channel for fund mobilization in Africa to perform their expected role of intermediation. In view of the avowed task on the banking industry in Africa, there is an urgent need to restructure the sector to properly reposition them to effectively accommodate the demand for credit from both the public and the private sector, so that savings and resources can be channeled towards productive investment. In a global study of business environment and micro finance institutions (MFIs) performance [21] finds cost-tostart business as one of the most influential variable in the performance of microeconomic institutions from 2004 to 2011. Using data from 45 countries and 124 MFIs, the regression outcome reveals that cost-to-start business positively influences increase in average loan balance, interest rate and business mark-up cost, hence revenue and cost performance of MFIs. Moreover, in a related study of bank market structure, competitiveness, and SME financing relationship in the European region in 2005, [22] find that cost-to-start business could influence multiple financing structure for start-ups, such that the more the cost of business set-up, the higher the need for diverse financial support sought in early stage of the firm's life, particularly where entrepreneurship is non-self-financing.

The above findings are in tandem with [23] theory of economic development which relates entrepreneurial innovation to financial development. Conventional economics opined that distribution of resources can be accomplished using the instrument of the stationary overall equilibrium framework. In like manner, Schumpeter defined innovation as the motivation propelling economic growth via allocation of resource mechanism. According to Schumpeter, capitalism's growth or progress is a vigorous and mutable process, which generates technical improvement that regularly alters the stability in a non-recursive manner. Innovation acquired on the platform of learning principles tends to have a tendency to reinforce and increase in a technologically inclined environment. This procedure is an enduring transformation that tasks the status quo, creates innovations and cause economy to be driven by resource allocation and re-allocation. 
This study employed secondary data from fortytwo (42) African economies (see appendix for list of economies), obtained from the World development indicators (WDI) database. Except

\section{Methodology}

Seychelles with high income, the other 41 countries are low income economies [24]. Details of data descriptions, sources, measurement and justification are presented in table 2 .

Table 2. Data: description, measurement and justification

\begin{tabular}{|l|l|l|}
\hline Variable description & Measurement/Proxies & $\begin{array}{l}\text { Literature } \\
\text { justification }\end{array}$ \\
\hline $\begin{array}{l}\text { Cs } b=\text { 'Cost-to-start } \\
\text { business' (a proxy for } \\
\text { entrepreneurship) }\end{array}$ & World Bank*/ \% of income (GNI) per capita & {$[20],[21]$} \\
\hline $\begin{array}{l}\text { Bc= Bank competitiveness } \\
\text { ratio }\end{array}$ & World Bank*/Commercial bank branch per 100,000 adults & {$[25]$} \\
\hline Lnrt= Lending rate & $\begin{array}{l}\text { World Bank*/Central Banks of respective economies/ proxy } \\
\text { for FI }\end{array}$ & {$[26] ;[27]$} \\
\hline $\begin{array}{l}\text { Dcinf= Depth of credit } \\
\text { information }\end{array}$ & World Bank*/ Depth of credit information index & {$[28]$} \\
\hline $\begin{array}{l}H c d=\text { Human capital } \\
\text { development }\end{array}$ & $\begin{array}{l}\text { World Bank*/Expenditure on education as \% of total } \\
\text { government expenditure / Research \& development: } \\
\text { production structure }\end{array}$ & {$[29] ;[30] ;[31]$} \\
\hline
\end{tabular}

Sources: Compiled by the authors. *https://data.worldbank.org/indicator/NV.IND.TOTL.KD.ZG?view

\subsection{Model Specification}

The underlying functional form of the theoretical arguments is implicitly presented as follows: $Y_{i t}=f\left(\alpha_{1}, X_{1 i t}^{\beta_{1}}, X_{2 i t}^{\beta_{2}}, X_{3 i t}^{\beta_{3}}, X_{4 i t}^{\beta_{4}}, u_{i}, \varepsilon_{i t}\right)$

Where $Y_{i t}$ stands for entrepreneurship development, which is proxied by cost-to-start business $(C s b)$. $X_{1}$ stand for Bank competitiveness $(B c) . \mathrm{Bc}$ is measured by the number of bank branches per 1,000 adults. It is suggestive that increased bank branching could promote banking competitiveness, promote financial inclusion, reduce the cost of starting business and hence improve entrepreneurial access to finance in the region. $X_{2}$ stands for financial intermediation (FI), proxied by lending rate $(L n r t)$. Competitive lending rate could decrease cost-to-start business (Csb), which is suggested could improve entrepreneurs' access to finance. $X_{3}$ stands for depth of credit information (Dcinf), and $X_{4}$ stands for Human capital $(H c)$. Both Dcinf and $\mathrm{Hc}$ are control variables in the model. They are expected to result in negative relationship with cost-to-start business $(C s b) . \mu_{i}$ is the specific cross-sectional error, and $\varepsilon_{i t}$ stands for idiosyncratic disturbances. In explicit form, and by applying the $\log$ transformation process, the model becomes:

$$
\begin{aligned}
& \log C s b_{i t}=\alpha_{1}+\beta_{1} \log B c_{i t}+\beta_{2} \log \operatorname{Lnrt}_{i t}+ \\
& \beta_{3} D c \text { inf }_{i t}+\beta_{4} \log H c_{i t}+\log c s b_{i t-1}+\varepsilon_{i t}
\end{aligned}
$$

The signs underlie are the a priori expectations. In line with dynamism of variable relations, this study treats the four variables on the right side as exogenous variables, while entrepreneurship development $(C s b)$ is endogenous variable.

\section{Empirical Results \& Discussion}

\subsection{Unit root test}

Presented in table $\mathbf{3}$ is the unit root test. The common unit root criteria, that is [32] produce level results for the five variable series; and under the individual unit root statistics, while [33] and ADF produces mixed stationary of $\mathrm{I}(0)$ and $\mathrm{I}(1)$, the PPFisher however produces level results. The mixed structure of stationary properties of the variables informs the regression techniques applied. 
Table 3. Unit root

\begin{tabular}{|l|l|l|l|l|l|l|l|l|}
\hline & \multicolumn{2}{|l|}{$\begin{array}{l}\text { Common unit root } \\
\text { process assumed }\end{array}$} & \multicolumn{7}{l|}{} \\
\hline Variable & LLC test & Stat. @ & IPS test & Stat.@ & ADF Fisher & Stat.@ & PP-Fisher & Stat.@ \\
& & & & & & & \\
\hline Csb & $-152.86^{* *}$ & $\mathrm{I}(0)$ & $-5.09^{* *}$ & $\mathrm{I}(0)$ & $134.01^{* *}$ & $\mathrm{I}(1)$ & $143.41^{* *}$ & $\mathrm{I}(0)$ \\
\hline Bc & $-13.34^{* *}$ & $\mathrm{I}(0)$ & $-1.63^{*}$ & $\mathrm{I}(1)$ & $138.43^{* *}$ & $\mathrm{I}(1)$ & $211.71^{* *}$ & $\mathrm{I}(0)$ \\
\hline Lnrt & $-12.60^{* *}$ & $\mathrm{I}(0)$ & $-2.01^{* *}$ & $\mathrm{I}(1)$ & $104.84^{*}$ & $\mathrm{I}(0)$ & $183.88^{* *}$ & $\mathrm{I}(0)$ \\
\hline Dcinf & $-4.44^{* *}$ & $\mathrm{I}(0)$ & - & - & $29.69^{* *}$ & $\mathrm{I}(1)$ & $56.68^{*}$ & $\mathrm{I}(0)$ \\
\hline Hc & $-10.69^{* *}$ & $\mathrm{I}(0)$ & $-35.69^{* *}$ & $\mathrm{I}(1)$ & $107.68^{*}$ & $\mathrm{I}(0)$ & $177.17^{* *}$ & $\mathrm{I}(0)$ \\
\hline
\end{tabular}

Source: by authors. * and ** indicates 0.05 and 0.01 levels of significance respectively. Stat. @ indicates stationarity at indicated levels.

\subsection{Correlation Result}

Correlation is a standardized measure of joint variability between two random variables, which reveals the direction and strength of the relationship, while guarding against error of multicollinearity. Of interest in table $\mathbf{4}$ is that negative relationship exists between the three explanatory variables $\mathrm{Bc}$, Dcinf, and $\mathrm{Hc}$, and the dependent variable Csb, while positive relationship suffices between the lending rate (Lnrt), (the proxy for FI) and Csb. These results conform to their $a$ priori expectation. On the former, it implies that improvement in the quality of the three variables would reduce start-up-cost and vice verse. The later outcome suggestively supports the 'availability doctrine', a feature of neoclassical doctrine of banking operation in developing economies, which indicates that in reality the price of credit matters less to investors but the availability [34]. Despite the growth of economic and financial liberalization policies, lending rate has been consistently high, while real savings rate has been negative in many African economies [24]. Uniquely, this outcome reoccurred in the regression results analyzed in section $\mathbf{4 . 4}$

Table 4. Correlation matrix table

\begin{tabular}{|l|l|l|l|l|l|}
\hline & \multicolumn{1}{|c|}{ Csb } & \multicolumn{1}{c|}{ Bc } & Lnrt & Dcinf & Hc \\
\hline Csb & 1.000 & & & & \\
\hline Bc & -0.244 & 1.000 & & & \\
\hline Lnrt & 0.211 & 0.001 & 1.000 & & \\
\hline Dcinf & -0.247 & 0.244 & 0.021 & 1.000 & \\
\hline Hc & -0.182 & -0.062 & -0.051 & 0.076 & 1.000 \\
\hline
\end{tabular}

Source: computed by the authors

\subsection{Lag Length Order}

Optimal lag length of the variables was established to guide the limit of time dynamics fitted for the model. While three techniques- All information criterion (AIC), Final prediction error (FPE), and the LR criteria limit the lag length to four (4), Schwarz information criterion (SIC) and HannanQuinn information criteria (HQ) chose one (1) as lag length. The study therefore adopts lag length four (4) as optimum, as presented in Table $\mathbf{5}$. 
Table 5. Lag length order table

\begin{tabular}{|l|l|l|l|l|l|l|}
\hline Lag & \multicolumn{1}{|c|}{ LogL } & \multicolumn{1}{c|}{ LR } & \multicolumn{1}{c|}{ FPE } & AIC & \multicolumn{1}{c|}{ SC } & HQ \\
\hline 0 & -3814.26 & NA & $4.31 \mathrm{e}+09$ & 36.37 & 36.45 & 36.404 \\
\hline 1 & -2473.11 & 2605.6 & 15519.57 & 23.94 & $24.317^{*}$ & $24.032^{*}$ \\
\hline 2 & -2436.77 & 68.863 & 13937.08 & 23.731 & 24.607 & 24.075 \\
\hline 3 & -2398.10 & 71.459 & 12247.58 & 23.601 & 24.876 & 24.116 \\
\hline 4 & -2367.59 & $54.922^{*}$ & $11642.03^{*}$ & $23.548^{*}$ & 25.222 & 24.225 \\
\hline
\end{tabular}

Source: Computed by authors

\subsection{Regression Results}

First, the study examined the diagnostic results and the a priori expectation as bases of the analysis. The generalized method of moment (GMM) technique may be suitable in a dynamic micropanel data study, with likelihood of endogeneity bias problem; nevertheless in this study the Hausman test result favours the fixed effect against random ( see Table 6). Furthermore, both the fixed effect and the pool regression produce high standard error of regression of 51.1 and 76.08 respectively, which makes them less justified. The generalized method of moment GMM (EGLS) method has the lowest joint influence test instruments ( $\mathrm{J}$ stat.) of 14.11 with highest probability value of $51.7 \%$. As the J-statistics is relatively smaller and insignificant, it suggests that the instruments may be valid. The $\mathrm{R}^{2}$ result of 76.6 per cent is moderate, while its standard error of regression of 17.69 is relatively moderate. Moreover, the GMM (EGLS)'s coefficient results justify a priori, hence the technique may thus be preferred to the first difference and the orthogonal deviation techniques.

An examination of the results from the six techniques using the level of significance and $a$ priori criteria reveals that Bank competitiveness (Bc) negatively and significantly suggests cost-tostart business (proxy for entrepreneurship), except for the orthogonal deviation method. The outcome suggests that improvement in $\mathrm{Bc}$ policies may be panacea for entrepreneurial finance development. The demand and supply forces of capital is a mechanism that suggest that increased availability of supply could reduce price and thereof increase entrepreneurial demand by start-ups.

Next, the FI's proxy, that is lending rate, has four significant a priori expectations in the Pool, Fixed, GMM first difference, and GMM orthogonal regression techniques which suggests positive impact from lending rate to entrepreneurship development, while the GMM (EGLS) result does not justify a priori expectation. The results of the four techniques- the pool et al. suggests that, given that the region is dominated by bank-led financial system, neoclassical doctrine of 'availability doctrine' operates. That is, entrepreneurial investment enthusiasts would more likely have to respond positively to increase in lending rate, as the correlation results in table $\mathbf{4}$ also corroborate. It suggests that though, the result supports the McKinnon-Shaw financial liberalization and nonrepressiveness of interest rate for investment development in developing countries, the banking institution's high lending rate may have been unhelpful for start-up-entrepreneurs in the region. Keeping interest rate below the market determined and government limits for bank deposits and loans in developing economies were challenged by the McKinnon-Shaw financial repression framework [11]. The Keynesian school's investment policy however suggests that high interest rate could frustrate entrepreneurial investment in capital scarce economies. The Keynes's theorem that savings is of private virtue but public vices may further inform the reason why high lending rate, at second digit, would be inimical to start-up entrepreneurship in developing economies, since capital formation that could moderate lending rate downwards is a function of public savings.

The outcome of the two control variables, that is depth of credit information and human capital capacity are in line with a priori expectations, as both show negative sign. The depth of credit information (Dcinf) negatively impacts cost-to-start business, a driving force for entrepreneurship. Similarly, the next result suggests that human capital capacity negatively impacts the cost- to-start business, hence can increase entrepreneurial capacity. 
Table 6. Dependent variable: cost-to-start business (Csb), proxy for entrepreneurship

\begin{tabular}{|c|c|c|c|c|c|c|}
\hline Variables & Pool & $\begin{array}{l}\text { Fixed } \\
\text { effect }\end{array}$ & $\begin{array}{l}\text { Random } \\
\text { effect }\end{array}$ & $\begin{array}{l}\text { GMM } \\
\text { (EGLS) }\end{array}$ & $\begin{array}{l}\text { GMM: 1st } \\
\text { difference }\end{array}$ & $\begin{array}{l}\text { GMM: orthogonal } \\
\text { deviations }\end{array}$ \\
\hline $\mathrm{Bc}$ & $\begin{array}{l}-1.829 * * * \\
{[-4.169]}\end{array}$ & $\begin{array}{l}-8.339 * * * \\
{[-3.403]}\end{array}$ & $\begin{array}{l}-2.734 * * * \\
{[-3.139]}\end{array}$ & $\begin{array}{l}-0.257 * * * \\
{[-3.271]}\end{array}$ & $\begin{array}{l}-0.323 * * * \\
{[-4.389]}\end{array}$ & $\begin{array}{c}0.003 \\
{[0.077]}\end{array}$ \\
\hline Lnrt & $\begin{array}{l}1.489 * * * \\
{[4.245]}\end{array}$ & $\begin{array}{l}5.282 * * * \\
{[9.761]}\end{array}$ & $\begin{array}{l}3.887 * * * \\
{[8.540]}\end{array}$ & $\begin{array}{l}-0.085 \\
{[-1.070]}\end{array}$ & $\begin{array}{l}0.085 \\
{[1.232]}\end{array}$ & $\begin{array}{l}0.214 * * * \\
{[8.397]}\end{array}$ \\
\hline Dcinf & $\begin{array}{l}-6.839 * * * \\
{[-3.859]}\end{array}$ & $\begin{array}{l}-0.507 \\
{[-0.333]}\end{array}$ & $\begin{array}{l}-2.366 \\
{[-1.641]}\end{array}$ & $\begin{array}{l}-0.785^{*} \\
{[-1.743]}\end{array}$ & $\begin{array}{l}-1.091 * * * \\
{[-5.955]}\end{array}$ & $\begin{array}{l}-0.984 * * * \\
{[-17.510]}\end{array}$ \\
\hline $\mathrm{Hc}$ & $\begin{array}{l}-2.401 * * * \\
{[-3.584]}\end{array}$ & $\begin{array}{l}-2.965 * * * \\
{[-2.883]}\end{array}$ & $\begin{array}{l}-2.998 * * * \\
{[-3.485]}\end{array}$ & $\begin{array}{l}-0.474 * * \\
{[-2.343]}\end{array}$ & $\begin{array}{l}-1.421 * * * \\
{[-15.694]}\end{array}$ & $\begin{array}{l}-0.359 * * * \\
{[-9.018]}\end{array}$ \\
\hline $\operatorname{Csb}(-1)$ & - & - & - & $\begin{array}{l}0.670 * * * \\
{[7.814]}\end{array}$ & $\begin{array}{l}0.648 * * * \\
{[162.71]}\end{array}$ & $\begin{array}{l}0.649 * * * \\
{[357.58]}\end{array}$ \\
\hline $\mathrm{R}^{2}$ & 0.169 & 0.656 & 0.21 & 0.766 & - & - \\
\hline F-statistics & 19.070 & 14.07 & 2.664 & - & - & - \\
\hline S.E. of Regr. & 76.08 & 51.91 & 0.019 & 17.693 & 22.305 & 16.282 \\
\hline $\begin{array}{l}\text { Instrument } \\
\text { Rank }\end{array}$ & - & - & 15 & 21 & 42 & 42 \\
\hline J-Statistics & - & - & - & 14.11 & 36.73 & 38.26 \\
\hline Prob.(J-stat.) & - & - & 0.141 & 0.517 & 0.481 & 0.412 \\
\hline
\end{tabular}

Source: Computed by the authors .*,**, and *** denote levels of significance @ $0.1,0.05$, and 0.01 respectively. The figures brackets $[. .$.$] are the t-statistics.$

\subsection{Hausman Test}

Fixed effect against random effect

The Hausman test result upholds the alternative hypothesis that fixed effect may be better than the random as presented in table 7 .

Table 7. Hausman test table

\begin{tabular}{|l|l|c|l|}
\hline Test Summary & chi-sq. statistics & chi-sq. d.f. & prob. \\
\hline Cross-section random & 33.416961 & 4 & 0.0000 \\
\hline
\end{tabular}

Source: Computed by the authors.

\subsection{Other Diagnostic Test}

Model stability test: The variables situate on the diameter within the circle which suggests stability of the model, hence suitable for the regression. 


\section{Summary of Findings, Conclusion and Recommendations}

\subsection{Summary of Findings \& Conclusion}

The study tests the supply lead-growth hypothesis in forty-two (42) African economies, with the proposition that bank competitiveness may matter in the relationship, using multivariate panel regression methodology. Two exogenous variablesbank competitiveness and lending rate produce two findings. The first reveals that there is negative impact from bank competitiveness on cost-to-start business, a proxy for entrepreneurship, which suggests that the higher the rate of bank competiveness would reduce cost-to-start business, ceteris paribus, which transmits to improved entrepreneurial capacity and development. Secondly, lending rate, which stands as proxy for FI has positive impact on cost-to-start business, which indicates that high lending rate is detrimental to cost-to-start business (the proxy for entrepreneurship) and hence a set-back to entrepreneurship development. The result implies that overtime, in agreement with endogenous growth theory, and many empirical findings that the link from finance - entrepreneurship- growth of [5] and of [35], and the high lending rate being experienced in African economies increase startup-cost and may have been unhelpful for entrepreneurship development. Thirdly, the depthof-credit information and human capital development negatively and independently impacts cost-to-start business, which may validate the substantive theory that information symmetry and human capital positively drive financial development; and therefore, are catalysts of entrepreneurial development. In conclusion, the study upholds the proposition that competitive finance and the order of its structure matters for entrepreneurial development in the African region.

\subsection{Recommendations}

The study recommends as follows: first, reduction in monetary policy rate by monetary authorities, an interest cost which constitute the highest weight in market lending rate across the economies. Secondly, financial restructuring policies to attract and build-up development finance institutions to encourage entrepreneurship, particularly the startup entrepreneurs, such as venture capital, pension funds, endowment funds, etc would be helpful. Thirdly, government liberalization policies should be furthered at inducing bank competitiveness, by relaxing the capital requirements for rural banking licenses; encourage bank branching through fiscal incentives, digital and technology induced banking.

\section{Acknowledgements:}

The authors acknowledge the moral and financial support from Covenant University, Ota, Nigeria in carrying out this study and paying for the initial conference and publication fees.

\section{References:}

[1] Eke, P.O., Okoye, L. U., Evbuomwan, G.O. (2018). A Dynamic Analysis of the Nexus between Entrepreneurship, Human Capital Development and Financial Deepening: Evidence from Selected African Economies. Journal of Applied Economic Sciences, vol. XIII, Fall 5(59): 1344 - 1356

[2] Mamiko Y. A. and Naoyuki Y. (2006). Concept of Competitiveness in the Financial Sector. Financial Research and Training Center, 2006 Discussion Series 1-35.

[3] Eke, O. Patrick, Achugamonu, B. Uzoma, Yunisa, A. Simion, and Osuma, G. Osagie (2020). Macroeconomic risks and financial sector stability: the Nigerian case. DECISION., Springer.1-19

[4] World Bank (1993). The East Asian Miracle: Economic Growth and Public Policy. New York NY, Oxford University Press World Bank (2017). World Bank list of economies (June). Retrieved from http://iccmoot.com/wpcontent/uploads/2017/07/World-Bank-List-ofEconomies.pdf, accessed 2nd Oct., 2018

[5] King, R. G. and Levine, R. (1993). Finance, Entrepreneurship, and Growth: Theory and Evidence. Journal of Monetary Economics, 32: 513-542.

[6] Somoye, R.O. C. (2013). The impact of finance on entrepreneurship growth in Nigeria: A co-integration Framework. ACRN Journal of Entrepreneurship Perspectives, 2(2): 21-45

[7] Sen, A. K. (1999). Development as freedom. New York: Knopf

[8] Eke, P. O., Adetiloye, K. A., Adegbite, E. O., Okoye, L.U. (2017). A co-integration Analysis of Interest rate spread and Corporate bond market Development in selected African economies. Journal of Applied Economic Sciences, vol. XII, Fall 6(52):1654-1667.

[9] Rajan, R. G. and Zingales, L. (2003). Banks and markets: the changing character of European finance. NBER working paper series, retrieved from 
hpp://www.nber.org.papers/w9595, accessed Dec. 27, 2016:1-78

[10] Eke, P. O., Adetiloye, K.A., Adegbite E.O. (2020). An Analysis of Bond Market Liquidity and Real Sector Output in selected African Economies. E\&M Economics and Management, 23(4), 166-182.

[11] Eke, P. O. (2017). Interest Rate Macrostructure, Corporate Bond Market Development and Industrial Output in selected African Economies. A Ph.D thesis, Covenant University, Ota, Nigeria http://eprints.covenantuniversity.edu.ng/12955 /1/Binder1.pdf

[12] Teriba, A. (2018). Harmonization of fiscal and monetary policies in Nigeria, Economic Insight. Retrieved from Businessdayonline.com, accessed on Thursday, April 19, 2018.

[13] Eke, P.O. and Omankhanlen, A. E. (2019). Public-Private Partnership and Financial Structure Development: Cointegration Lessons for selected sub-Sahara African Economies. Annals of Economics and Finance 20-2, 783802

[14] Achugamonu B. U., Taiwo J.N., Ikpefan A. O, Olorinola I.O., Okorie U.E (2016). Agent Banking \& Financial Inclusion: The Nigerian Experience. Proceedings of the 28th International Business Information Management Association Conference 9-10 November 2016, Seville, Spain.

[15] Mammadov, I. and Ahmadov, F. (2021). Financial Development and Economic Growth: Evidence from Azerbaijan. WSEAS TRANSACTIONS on BUSINESS and ECONOMICS, 18, 2021: 237-252

[16] Liu, Q., Lejot, P., and Arner, D. W. (2013). Finance in Asia, Institutions, Regulation and Policy. Routledge Advanced Texts in Economics and Finance, Taylor and Francis Group, London and New York: 49-90

[17] Ajagbawa, H. (2014). Entrepreneurship, Financial, and Economic Development: a literary Review. IOSR Journal Of Humanities And Social Science (IOSR-JHSS), 19(6), 85118.

[18] Yakubu, I.N., Abokor, A. H., and Balay, I. G. (2021). Re-examining the impact of financial intermediation on economic growth:evidence from Turkey. Journal of Economics and Development, vol. 23(2): 116-127

[19] Morales F. M (2003). Financial Intermediation in a model of growth through creative
Distinction. Cambridge University Press, 7(3), 363-393

[20] Dahou, K., Omar, H. I., and Pfister, M. (2009). Deepening African Financial Markets for Growth and Investment. NEPAD-OECD African Investment Initiative, Ministerial Meeting and Expert Roundtable, Nov. 11-12: 22-40

[21] El-Maksoud, S. A. (2016). Performance of Microfinance Institutions. A thesis submitted in fulfilment of the requirements for the Degree of Doctor of Philosophy. Cardiff Metropolitan University, Cardiff School of Management: 1-247

[22] Mercieca, S., Schaeck K., and Wolfe, S. (2009). Bank market structure, competition, and SME financing relationships in European Region. Journal of Financial Services, 36:137

[23] Schumpeter, J. (2012). Theorie der Wirtschaftlichen Entwicklung (The Theory of Economic Development) Leipzig: Dunker and Humblot, (translated by Redvers Opie, Cambridge, Massachusetts: Harvard University Press, 1934).

[24] World Bank (2017). IBRD, IDA Data (doingbusiness.org). World Development Indicator (WDI, 2017) Private sector database, www.data.worldbank.org/indicator

[25] Ojo, J. A. T. (2010). The Nigerian Maladapted Financial System: Reforming Tasks and Development Dilemma in Nigeria, Charted Institute of Banker Press, Nigeria: 1-49, 299342

[26] Bosworth, B. P. (2014). Interest rates and economic growth: are they related?, Center for Retirement Research, Boston College, http://crr.bc.edu/workingpaper2014-8, accessed November 13, 2015.

[27] Mu, Y., Phelps, P., Stotsky, J. G. (2013). Bond Markets in Africa. IMF African Department, International Monetary Fund Working Paper 13/12: 1-52.

[28] Alexe, C. M. and Alexe, C. G. (2017). Human Capital Practices drive Innovation in Romania. Procedia Engineering 181: 943-950.

[29] Djankov, S., McLiesh, C., and Shleifer, A. (2007). Private Credit in 129 Countries. Journal of Financial Economics 84: 299-329.

[30] McGuirk, H., Lenihan, H. and Hart, M. (2014). Measuring the impact of innovative human capital on small ?rms' propensity to innovate. Research Policy 44: 965-976

[31] Huggins, R., Prokop, D., Thompson, P. (2017). Entrepreneurship and the Determinants of Firm Survival within 
Regions: Human Capital, Growth Motivation and Locational Conditions. Entrepreneurship and Regional Development, 29 (3-4): 357-389.

[32] Levin, A., Lin, C. F., and Chu, C. (2002). Unit root in Panel Data: Asymptotic and Finite sample Properties. Journal of Econometrics, 108: $1-24$

[33] Im, H. S., Pesaran, M. H. and Shin, Y. (2003). Testing for unit roots in heterogeneous panels. Journal of Econometrics, 115: 53-74

[34] Matthews, K. and Thompson, J. (2014). The Economics of Banking, third edition. Wiley: 125-140

[35]Kar, M. and Öz?ahin, S. (2016). Role of financial development on entrepreneurship in the emerging market economies. ESK??EH?R OSMANGAZ? ÜN?VERS?TES? ??BF DERG?S?, ARALIK, 11(3): 131- 152.

\section{Contribution of Individual Authors to the} Creation of a Scientific Article (Ghostwriting Policy)

Eke Patrick, developed the title and wrote the abstract and introduction. Achugamonu Bede and Babajide Abiola collated the data and conducted the analysis as well as interpreted the result. Ashamu Sikiru proof-read the manuscript and made suggestions to the summary of finding, conclusion, and recommendation.

\section{Sources of Funding for Research Presented in a Scientific Article or Scientific Article Itself}

No direct funding was received from any source for the conduct of this research. However, Covenant University, Ota paid the publication fee for this article.

\section{Creative Commons Attribution License 4.0}

\section{(Attribution 4.0 International, CC BY 4.0)}

This article is published under the terms of the Creative Commons Attribution License 4.0

https://creativecommons.org/licenses/by/4.0/deed.e $\underline{\text { n US }}$

\section{Appendix}

List of 42 sampled African developing economies studied:

Botswana, Cameroon, Cote d'Ivoire, Central African Republic, Benin, Burkina-Faso, Burundi,
Angola, Kenya, Congo, Ghana, Guinea, Gambia, Gabon, Algeria, Djibouti, Mali, Mauritania, Niger, Nigeria, Senegal, Sierra-Leone, Malawi, Mozambique, Rwanda, Seychelles, Tanzania, Uganda, Zambia, Zimbabwe, Namibia, Chad, Democratic Republic of Congo, Equatorial Guinea, Guinea Bissau, Madagascar, Sao-tome and Principe, Sudan, Liberia, Cape Verde, Togo, and Comoros 